\title{
An Empirical Analysis Of The Interest Rate-Vehicle Purchase Decision Nexus In South Africa
}

Joseph Chisasa, University of South Africa, South Africa

Winnie Dlamini, University of South Africa, South Africa

\begin{abstract}
The domestic passenger car market has witnessed substantial growth in South Africa. At the same time, bank repossessions and black-listing of defaulting borrowers have increased in sympathy. This paper empirically examines the link between interest rates and the borrowers' decision to purchase a passenger vehicle in South Africa. We use monthly time series data of passenger vehicles purchased, household income, fuel prices, prime interest rates and producer price index for manufacturers from January 1995 to December 2011. With passenger vehicle unit purchases as the dependent variable, we obtain OLS estimates of the passenger vehicle purchase function. Results show that there is a negative, but insignificant, relationship between interest rates and passenger vehicle purchases in South Africa. Holding other factors constant, a $1 \%$ increase in interest rate results in a $0.9 \%$ decrease in passenger vehicle purchases. Household income, fuel price and producer price index are observed to have a positive and insignificant impact on the decision to purchase a passenger vehicle. Our results have policy and decision making implications to lenders and borrowers, respectively.
\end{abstract}

Keywords: South Africa; Interest Rates; Passenger Car; Purchase Decision

\section{INTRODUCTION}

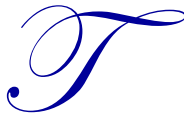

he Personal Finance Research Unit (PFRU, 2012) contends that, even though information about interest rates, household income and expenditure is available, very little is known about the purchasing behaviour of households when acquiring assets such as vehicles and also how their vehicles are financed. While most literature on purchasing focuses on purchasing management for organizations, there remains a challenge of addressing personal purchasing behaviour. Every household's (single individual or family) purchasing decision affects its financial bearing in the same way as it would affect any business. Therefore, it is imperative to address personal purchasing decisions of vehicles and enhance future responsible purchases. In the literature, it has been observed that consumer behaviour turns out to be causally related to the consumers' purchase choice (Lane \& Potter, 2007; van Rijnsoever, Farla \& Dijst, 2009; Majeske, Menk, and Serocki, 2010).

Consumers may have a difficult time making a financially rational choice in the utility-maximizing sense (Wonder, Wilhelm \& Fewings, 2008:244). To date, research has been conducted to determine factors which influence purchase decisions, such as food (Cheng, Sims, and Teegen, 1997; Munchanda, Ansari, and Gupta, 1999; Makatouni, 2002; Rimal, Moon, and Balasubramanian, 2005). To our knowledge, no study has been conducted on the purchase criteria for passenger cars in South Africa. Naude \& Badenhorst-Weiss (2011), for instance, investigated supply chain management problems encountered by South African automotive component manufacturers and the extent of these problems. It is the aim of this paper to identify the factors which influence South African drivers to purchase passenger cars given the needs and wants competing for the ever-constrained personal budget. More specifically, the purpose of this paper is to empirically determine the link between interest rates and the borrower's behaviour when making credit purchases of passenger vehicles in South Africa. The knowledge is worthwhile for lenders to understand the factors driving the purchasing decision in order to formulate 
policies and measures that would lead to the decrease of credit default and enhance responsible purchasing. Furthermore, the government will be able to make appropriate policies based on sound knowledge of the implications our findings have for consumer self-protection and financial literacy education efforts.

The article provides a theoretical background, followed by a discussion of the data and methodology, results and discussion of results, conclusions, and recommendations.

\section{Trends In Vehicle Purchases}

Over the past few years, purchasing of new passenger vehicles in South Africa has experienced considerable growth (Moodley, 2007). The proliferation of new models of passenger vehicles (for example, the Kia Sportage - pictured below - Hyundai ix35, BMW X6, among others) has received substantial growth largely supported by credit purchases (National Association of Automobile Manufacturer of South Africa (NAAMSA, 2012)).

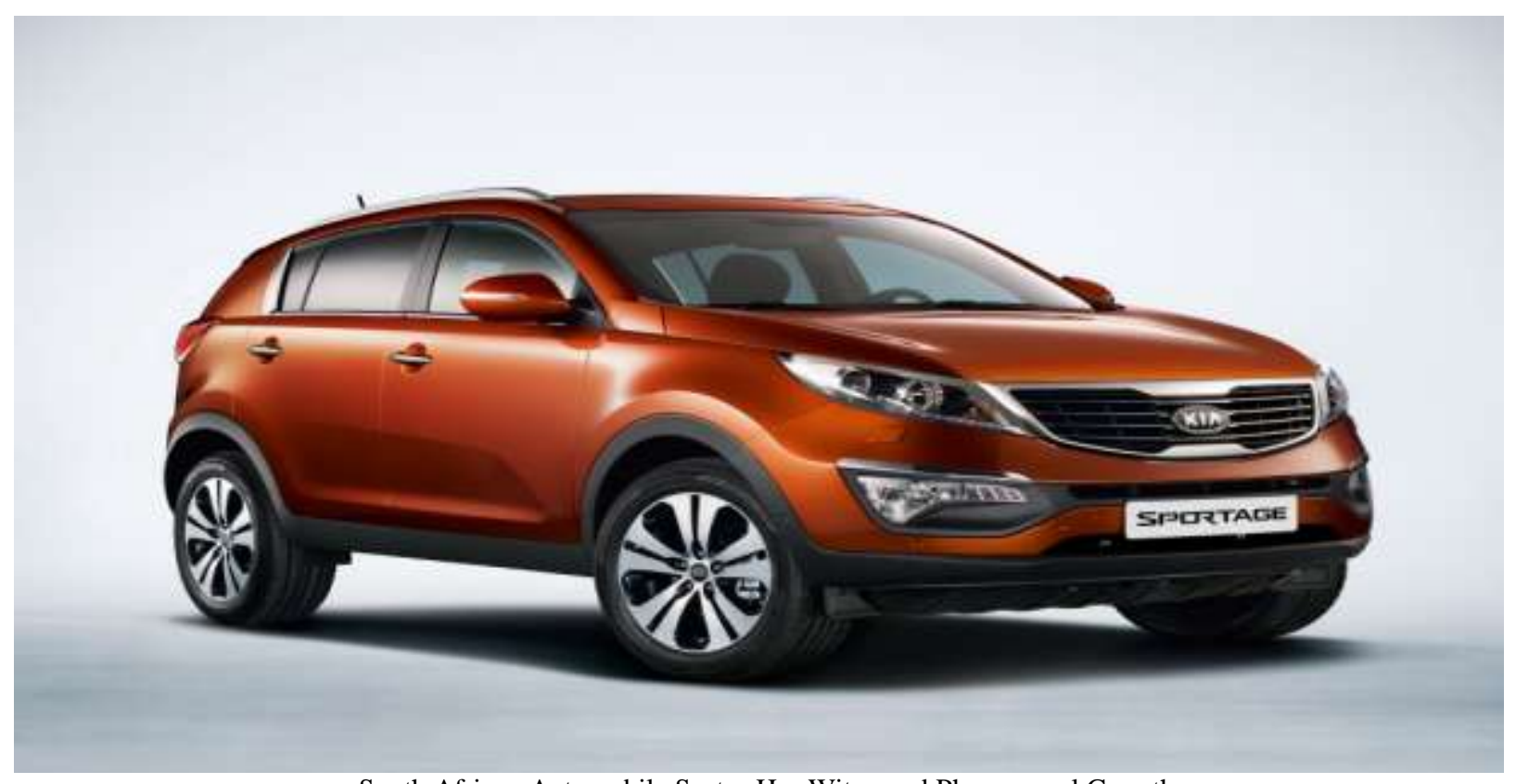

South African Automobile Sector Has Witnessed Phenomenal Growth

NAAMSA reported that the sales of new vehicles have increased by $4.8 \%$ year-on-year since 2004 (Moodley, 2007:2). South Africa has been one of the best performing automobile markets in the world in recent years. New vehicle sales figures soared to record-breaking levels contributing $6.2 \%$ to South Africa's Gross Domestic Product (GDP) in 2011 up from 5.9\% in 2010. The sector's contribution to GDP peaked at 7.35\% in 2006 before retreating in the subsequent years. For example, in 2006, sales increased by $14.4 \%$ to just under 650,000 units, generating revenue of R118.4 billion (NAMSA, 2012). Following the 2008 global meltdown, sales slowed down in response to the turmoil. However, new car sales recovered 5.67\% by December 2011 year-on-year compared to the same period the previous year. This was achieved amid increases in producer inflation (8.92\%), consumer spending (4.74\%) and consumer inflation (6.44\%).

Such growth is influenced by various economic, social, and personal factors (Bhasin, 2010). In the midst of this, one gets the impression that the economic climate in South Africa has improved. However, at the same time, when taking into account the rate at which passenger vehicles are repossessed and the increasing number of individuals that are defaulting and blacklisted because of short payment, then one begins to notice the inverse relationship that exists (see Table 1). An examination of quarterly credit trends for the period March 2008 to December 2010 shows that a significant portion of credit granted by banks never finds its way back, resulting in nonperforming assets in bank portfolios. Table 1 shows a decreasing trend of consumers in good credit standing. 
The National Credit Regulator reported in the Credit Bureau Monitor that there were 18.51 million credit-active consumers at the end of December 2010. Of these, the percentage of consumers without good standing (impaired records) increased to $46.5 \%$, comprising $17.8 \%$ consumers in three months or more in arrears, $14.6 \%$ of consumers with adverse listings, $14.1 \%$ of consumers with judgments and administration orders. Table 1 shows a detailed breakdown of the nature of impairments.

Table 1: Credit Standing Of Consumers

\begin{tabular}{|l|l|l|l|l|l|l|l|l|l|l|l|l|l|l|}
\hline & Mar'08 & Jun'08 & Sep'08 & Dec'08 & Mar'09 & Jun'09 & Sep'09 & Dec'09 & Mar'10 & Jun'10 & Sep'10 & Dec'10 \\
\hline $\begin{array}{l}\text { Good standing } \\
\text { (\#) million }\end{array}$ & 10.55 & 10.38 & 10.43 & 10.26 & 10.15 & 9.94 & 9.92 & 9.89 & 9.73 & 9.84 & 9.86 & 9.90 \\
\hline $\begin{array}{l}\text { Good standing } \\
(\%)\end{array}$ & 61.6 & 60.4 & 59.5 & 58.4 & 57.6 & 55.9 & 55.1 & 54.7 & 54.0 & 53.1 & 53.7 & 53.5 \\
\hline Current (\%) & 45.1 & 44.9 & 44.9 & 43.6 & 42.3 & 41.7 & 41.2 & 40.5 & 39.5 & 39.2 & 39.9 & 39.2 \\
\hline $\begin{array}{l}1-2 \text { months in } \\
\text { Arrears (1\%) }\end{array}$ & 16.5 & 15.5 & 14.6 & 14.8 & 15.3 & 14.2 & 13.9 & 14.2 & 14.5 & 13.9 & 13.8 & 14.3 \\
\hline $\begin{array}{l}\text { Impaired } \\
\text { records (\#) }\end{array}$ & 6.59 & 6.79 & 7.10 & 7.30 & 7.46 & 7.85 & 8.09 & 8.18 & 8.37 & 8.59 & 8.49 & 8.61 \\
\hline $\begin{array}{l}\text { Impaired } \\
\text { records (\%) }\end{array}$ & 38.4 & 39.6 & 40.5 & 41.6 & 42.4 & 44.1 & 44.9 & 45.3 & 46.0 & 46.9 & 46.3 & 46.5 \\
\hline $\begin{array}{l}3+\text { months in } \\
\text { arrears (\%) }\end{array}$ & 14.3 & 15.3 & 15.7 & 15.1 & 15.3 & 16.8 & 17.0 & 17.3 & 17.2 & 17.3 & 17.0 & 17.8 \\
\hline $\begin{array}{l}\text { Adverse } \\
\text { listings (\%) }\end{array}$ & 12.8 & 13.1 & 12.2 & 13.8 & 14.2 & 14.2 & 14.7 & 14.6 & 15.0 & 15.6 & 15.4 & 14.6 \\
\hline $\begin{array}{l}\text { Judgments and } \\
\text { Administration } \\
\text { orders (\%) }\end{array}$ & 11.3 & 11.2 & 12.6 & 12.7 & 12.9 & 13.1 & 13.3 & 13.3 & 13.7 & 13.9 & 13.9 & 14.1 \\
\hline $\begin{array}{l}\text { Credit-active } \\
\text { consumers (\#) }\end{array}$ & 17.4 & 17.17 & 17.53 & 17.56 & 17.61 & 17.79 & 18.01 & 18.07 & 18.21 & 18.32 & 18.35 & 18.51 \\
\hline Souc: Cref B & & & & & & & & & & \\
\hline
\end{tabular}

Source: Credit Bureau Monitor

\section{Understanding Consumer Buying Behavior}

Moodley (2007:13) contends that consumers purchase products not to satisfy their needs but to express their personality. In search for positive reception, various economic, social, and personal factors influence daily buying decisions. He further asserts that social gatherings and events present opportunities for consumers to show off their new products; for example, vehicles. However he presumes that this kind of behavior tends to breed irrational buying behavior. Ultimately, overspending and poor money management results. This happens because purchasers do not frequently have relevant information on overuse of credit and other financial difficulties (Brennan \& Alexiades, 2005). Hence, this paper looks at the consumer buying process which is briefly discussed below.

\section{Stages of the Consumer Buying Process}

Purchasing a personal vehicle is a complex process. According to Sheth, Mittal and Newman (1999), the decision-making of purchasing durable products incorporates questions such as whether to purchase, what to purchase, when to purchase, from whom to purchase, and how to pay for it. Therefore, the decision-making process needs to be taken carefully. Kapoor, Dlabay, and Hughes (2010) suggest that this difficult exercise comprises of four phases, as shown in Figure 1. The authors further stress that the actual purchasing is only one stage of the process and they also submit to the notion that not all decision processes lead to a purchase. It is important to note that not all consumer decisions consist of all the phases. 


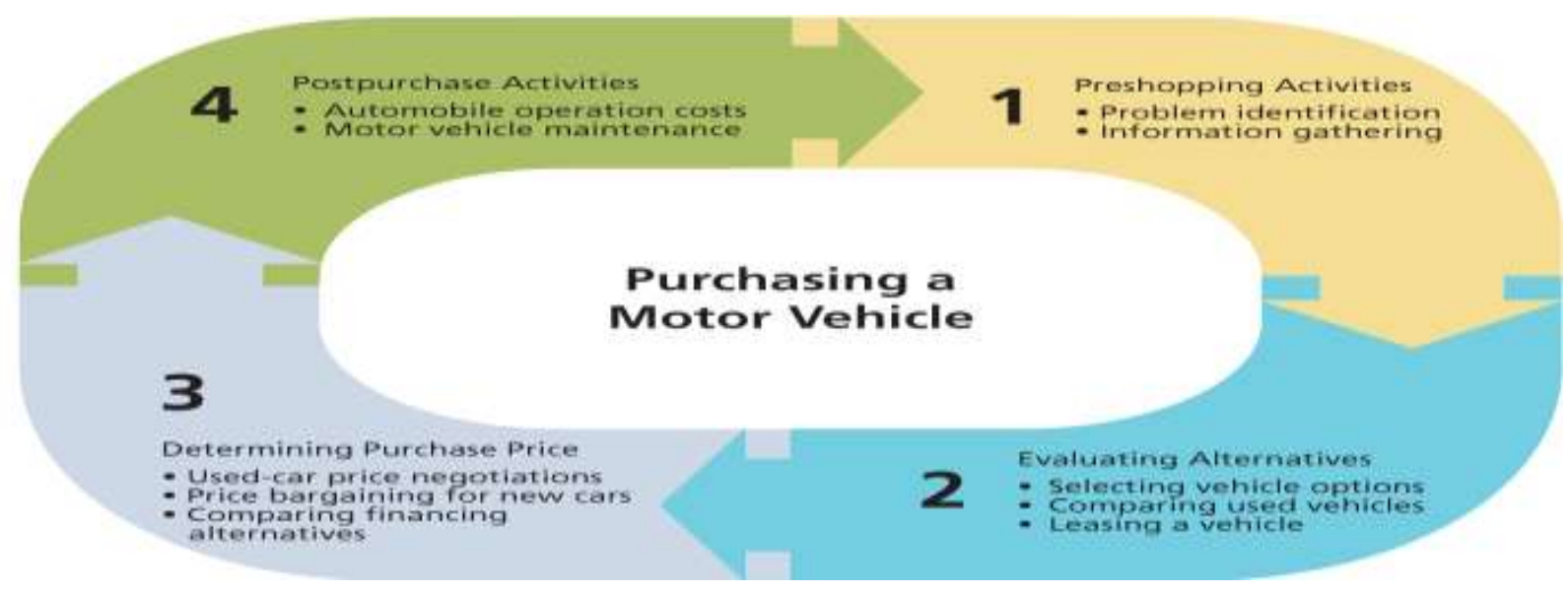

Figure 1: Phases Of Consumer Decision-Making Process For A Personal Vehicle Source: rci.rutgers.edu/ boneill/presentations/FPF-Chapter-6.ppt

\section{Factors Influencing The Personal Vehicle Purchasing}

Personal vehicle purchasing is influenced by a wide variety of factors (Lane and Potter, 2007:1085) which can be categorized as personal, economic, social, regulatory environments, vehicle performance, and application. In addition to these issues, Shah (2010) cites important subjective psychological factors - for private attitudes, lifestyle, personality and self-image, and, additionally, for fleet purchasers - risk-perception, corporate culture, and company image. Opportunity costs of daily buying decisions are commonly overlooked with regard to trade-offs such as:

- $\quad$ higher costs when buying on credit

- $\quad$ buying poor quality items

- $\quad$ buying brands that are difficult to obtain repair service

- $\quad$ buying by mail to save time and money but having a difficult time returning the item using time and effort to comparison shop.

Amongst the myriad of determinants of the vehicle purchase decision by South Africans, this paper focuses on the economic factors; that is, interest rates, fuel prices, the price of cars and household income. The psycho-social factors have been mentioned in passing but do not form part of the analysis.

\section{Interest Rates}

Financial contracts for consumer durables typically consist of multiple terms and conditions, including a price (interest rate) and a payment period, which makes it unlikely that the financial costs of different contracts are exactly the same. Dasgupta, Siddart, and Silva-Risso (2007:490) analysed the behaviour of consumers with respect to the choice of the funding method for automobiles (Banerjee, 2010:10) by comparing the credit and leasing options. It was argued that consumers are myopic and prefer contracts with lower payment streams, even when they have higher total costs. They also argue that consumers are more likely to lease than to finance cars with higher maintenance costs because this provides them with the option to return the car before maintenance costs become too high. Contributing to the debate on the role of interest rates on the purchase decision, Wonder et al. (2008:266) opined that respondents preferred low interest rates, a high rebate, and downpayment. Contractual interest rate and the duration of the loan (whether short- or long-term) were found to be the key determinants of consumer loan choice. This view contrasts that of Doyle (1997:1) who postulates that an interest rate increase may not affect real motor vehicle sales if the automakers are able to counteract the rate increases with lower prices. 


\section{Household Income}

Mogridge (1967:19) posits that the fundamental concept is that the average person of a given income level spends a given quantity of money on the purchase of cars. He further argues that there is a function which gives, for every income level, an average expenditure on a car purchase. More recent studies have shown that there is a positive relationship between income levels and vehicle purchase decisions by individuals (Feng, Wang, and Zeng, 2011:594). For example, Nagai, Fukuda, Okada, and Hashino (2003:135) found that two- and four-wheeled vehicle ownership in Thailand is highly dependent on income levels. Similarly, Diaz-Olvera, Plat, and Pochet (2008:3) and Blumenberg and Pierce (2012) suggest that income - or lack of it - influences household transportation decisions and the way in which individuals choose to travel. They argue that low-income households are less likely to own cars (Rahman, 2011:1276) and more likely to travel by other modes of transportion other than motor vehicles.

\section{Fuel Prices}

McManus (2007) examined the link between fuel prices and sales of cars and trucks in the U.S. In the analysis, McManus acknowledged that economic theory predicts a direct link between fuel prices and SUV sales, and more broadly between fuel prices and vehicle sales. It is argued that to make a rational choice at the time of purchase, the shopper needs a prediction (simple or sophisticated) of what future fuel prices are likely to be. McManus presented evidence that a significant portion of changes in vehicle prices can be explained by changes in fuel prices. In effect, rising fuel prices lower the prices of automobiles. Specifically, the negative impact of rising fuel prices on vehicle prices is greater for less fuel efficient vehicles than for more fuel efficient vehicles.

\section{Price Of The Car}

In Turkey, Alper and Mumcu (2007:1789) estimated the demand for new automobiles using quarterly data on price, quantity, quality, country of origin, and product characteristics of the new automobile sales market demand during the period 1996-1999. Using the dynamic Generalised Least Squares Estimation method, they showed that country of origin, as well as quality, matter for automobile demand in Turkey. It was also observed that the demand for new automobiles is price inelastic in the short run. Similarly, Zhan and Vrkljan (n.d.) in South-Western Ontario investigated the older drivers' (70-90 years old) perceptions of vehicle safety and how they influence their vehicle purchase. Safety was superseded by other purchasing considerations - most notably, price. Price was identified and emphasised as the key factor that influenced vehicle purchase decisions. Fuel efficiency, which participants considered in their overall cost of the vehicle, was also listed as an important consideration in the vehicle purchase decision process.

\section{DATA AND METHODOLOGY}

The study employs a quantitative research design using secondary data. In this section, we describe the modeling of the factors which influence the vehicle purchase decision in South Africa. We describe the data, the model specification, and variable operationalisation. We then discuss the results of the proposed model and conclude with details on model prediction.

\section{Data}

Secondary data were drawn from different sources. First, the number of passenger vehicle monthly sales, which was proxied as the dependent variable, was obtained from the National Automobile Association of South Africa (NAAMSA). The data covered the period January 1995 to March 2012. In the absence of monthly data for vehicle price increases, the producer price index for manufacturers was used as the proxy for vehicle prices (SARB, 2012). Fuel prices were obtained from the South African Petroleum Association. We used the price of petrol as the proxy for fuel price. We assumed that passenger vehicles are powered by petrol. We acknowledge the fact that other passenger vehicles are powered by diesel, but these constitute an insignificant proportion of the total passenger vehicles. The prime lending rates were obtained from the South African Reserve Bank (SARB) website. We used the prime lending rate because the ultimate rates at which vehicle loans are secured by borrowers are institution and individual specific. The loan rate is the sum of the bank's prime rate plus a default risk premium. Default 
probabilities are not uniform; therefore, we used a uniform measure of interest rate (prime rate). Finally, the disposable household income data was also obtained from the FinScope South Africa Press Release (January, 2009).

\section{Model Specification}

As the objective of this study was to determine the link between passenger car purchase decisions and interest rates, we hypothesize that interest rates have a negative and significant influence on the decision to purchase a passenger car. The null and alternative hypotheses are therefore stated as:

$\mathbf{H}_{\mathbf{0}}$ : Interest rates negatively and significantly influence the decision to purchase a passenger car in South Africa.

$\mathbf{H}_{\mathbf{a}}$ : Interest rates do not negatively and significantly influence the decision to purchase a passenger car in South Africa.

We use the Ordinary Least Squares (OLS) to estimate the following function:

$\mathrm{V}_{\mathrm{p}} \quad=\mathrm{f}\left(\mathrm{X}_{1}, \mathrm{X}_{2} \ldots . \mathrm{X}_{\mathrm{n}}\right)$

Where: $\quad \mathrm{V}_{\mathrm{p}}$ is the vehicle purchase

$\mathrm{X}_{1}-\mathrm{X}_{\mathrm{n}}$ are the factors that influence the decision to purchase a passenger car

The hypothesized model is therefore specified as follows:

$$
\mathrm{V}_{\mathrm{p}} \quad=\beta_{0}+\beta_{1} \mathrm{FP}+\beta_{2} \mathrm{HI}+\beta_{3} \mathrm{IR}+\beta_{4} \mathrm{PPI}+\varepsilon_{\mathrm{t}}
$$

Where: $\mathrm{V}_{\mathrm{p}}=$ number of passenger vehicles purchased per month

$\mathrm{FP} \quad=\quad$ the monthly average fuel price per cubic litre

$\mathrm{HI} \quad=\quad$ monthly average household income

IR $=$ the prime overdraft lending rate per annum

PPI = the producer price index for the manufacturing sector

$\varepsilon_{\mathrm{t}} \quad=\quad$ white noise

$\mathrm{B}_{0}-\beta_{4}=$ the coefficients explaining the elasticities of explanatory variables. These values are constants determined by available technology

\section{EMPIRICAL ANALYSIS AND DISCUSSION}

\section{Preliminary Analysis}

Figure 2 shows quite an insightful trend between household income and passenger vehicle sales for the period under review. From 1995 to 2010, the trend of passenger vehicle sales and household income was not in tandem with vehicle sales trending higher. Interest rates (Figure 3) hit an all time low of 5.5\% in November 2010 since the highest in 1998 when the interest rates rocketed to 23.99 in June (Trading Economics, 2012). Since then, the interest rates have remained unchanged. 


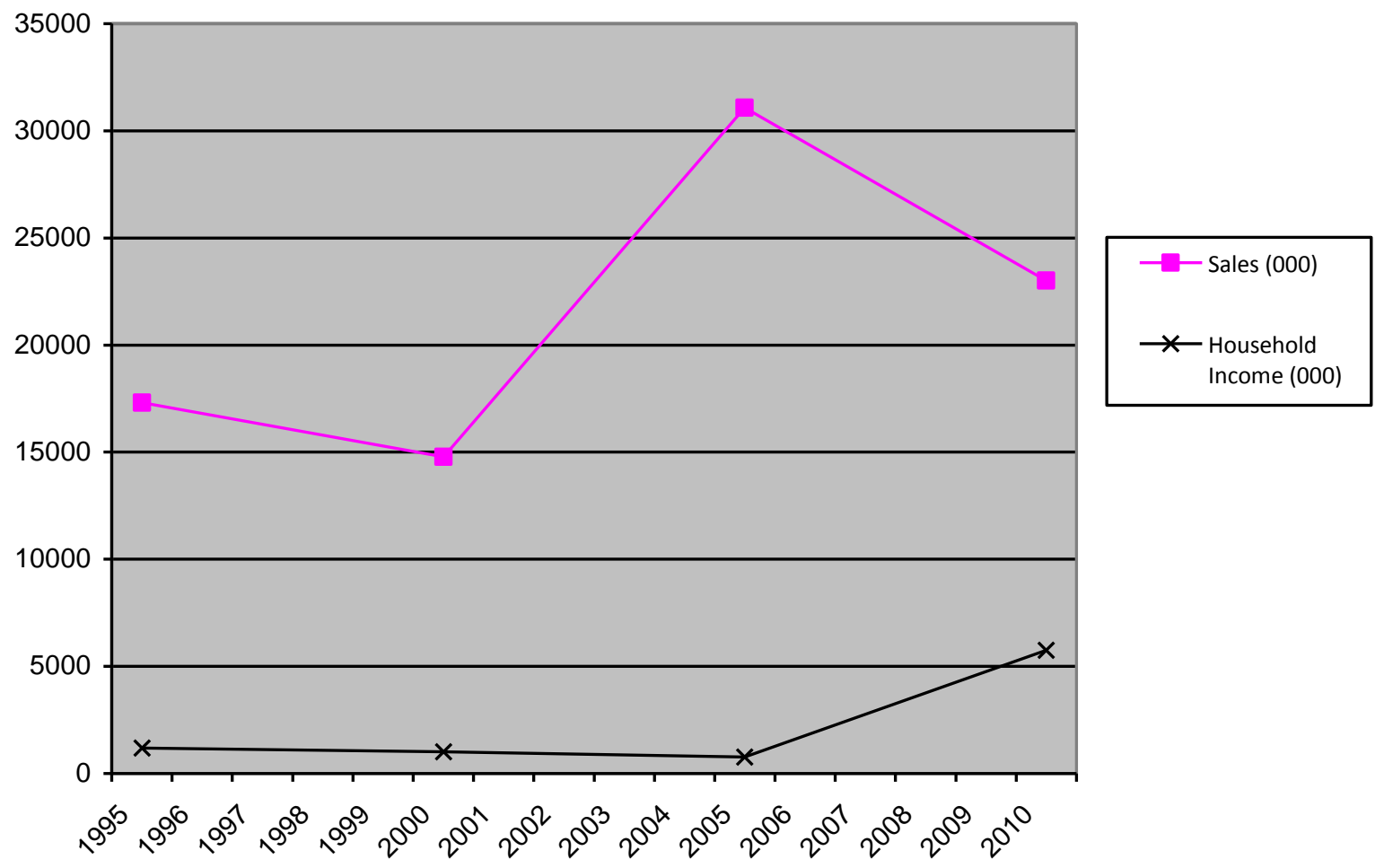

Figure 2: Trend Of Sales and Household Income Source: Author calculations

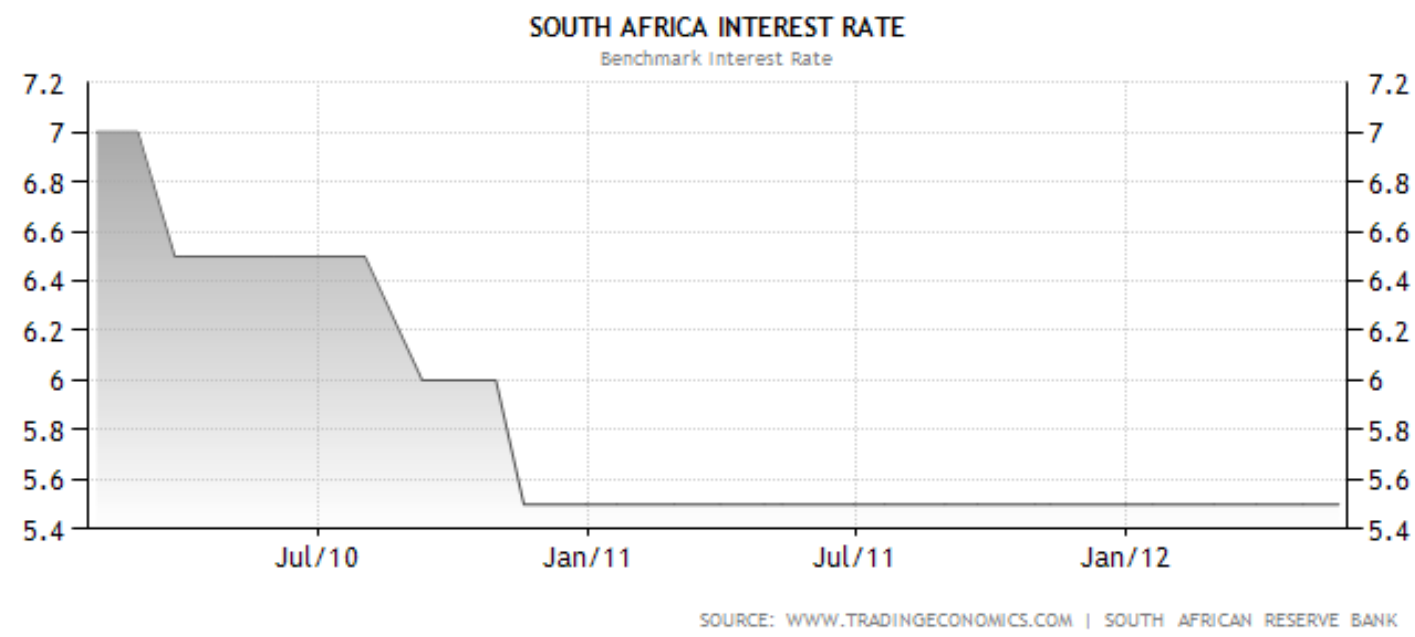

Figure 3: Trend Of Interest Rates

The drop in interest rates stimulated the increase of new vehicle purchases by $10.5 \%$ year-on-year to 42,617 units in April 2012 (Mail \& Guardian, 03 May, 2012). The National Association of Automobile Manufacturers of South Africa (NAAMSA) projected an improvement of $7.5 \%$ on the purchase of new domestic vehicles in 2012. All variables were log-transformed and unit root tests conducted to determine stationarity. 


\section{Unit Root Tests}

The data were subjected to unit root tests using the Augmented Dickey-Fuller Schwarz Info Criterion. At level with intercept, all variables were integrated of order one I(1). However, all the variables were observed to be integrated of order zero $\mathrm{I}(\mathrm{O})$ at first difference with intercept at $1 \%$ significance level while credit was stationary at $5 \%$. All variables were subjected to a second unit root test using the Phillips and Perron test and were confirmed to be integrated of order zero $\mathrm{I}(0)$ at $1 \%$, except credit which was integrated of order zero at $5 \%$. The null hypothesis that the data series have unit roots could not be accepted as a result. Table 2 summarises the unit root tests.

Table 2: Unit Root Tests

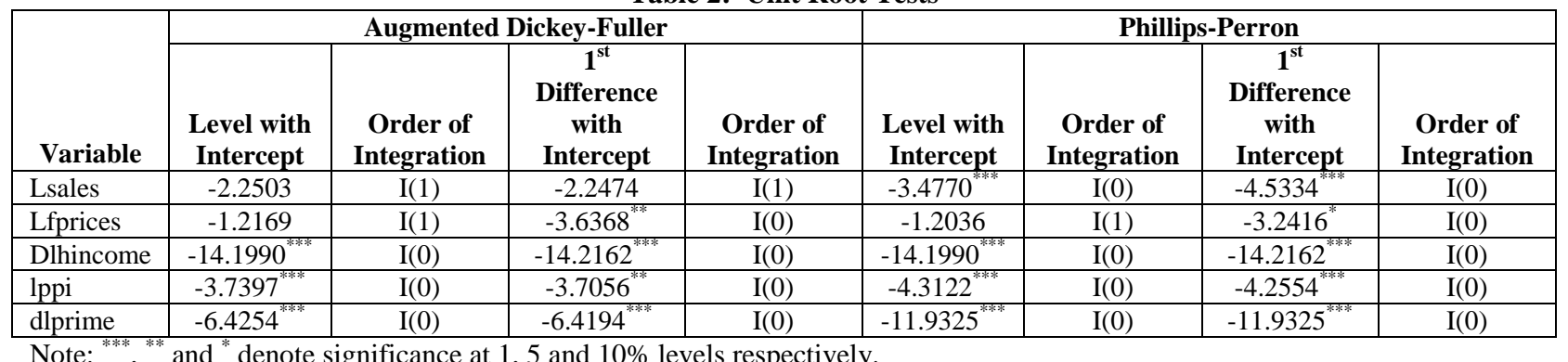

\section{MODEL ESTIMATION AND DISCUSSION}

After adjusting the data for stationarity, the econometric model was estimated using EViews version 7. In the first output, a low Durbin-Watson statistic was observed, suggesting evidence of the presence of serial autocorrelation. This was corrected by adjusting for AR(1). Table 3 presents the final estimates of the equation.

Table 3: The OLS Estimates Of The Passenger Vehicle Purchase Function

\begin{tabular}{|c|c|c|c|}
\hline Variables & Coefficient Estimates & t-Values & Significance \\
\hline CONSTANT & 9.9011 & 10.6394 & $0.0000^{* * * *}$ \\
\hline LFPRICE & 0.0988 & 1.3728 & 0.1715 \\
\hline DLHINCOME & 0.2233 & 0.6128 & 0.5408 \\
\hline LPPI & 0.0024 & 0.0894 & 0.9288 \\
\hline DLPRIME & -0.8724 & -1.8568 & 0.0649 \\
\hline $\operatorname{AR}(1)$ & 0.7215 & 14.0141 & $0.0000^{* * *}$ \\
\hline $\begin{array}{l}\mathrm{R}^{2}=0.74 \\
\text { F-statistic }=104.32\end{array}$ & \multicolumn{3}{|c|}{$\begin{array}{l}\text { Adjusted } \mathrm{R}^{2}=0.73 \\
\text { Durbin-Watson statistic }=2.32\end{array}$} \\
\hline
\end{tabular}

The diagnostic tests conducted satisfied apriori expectations in the estimated model. The relationship between interest rates and the passenger vehicle sales was observed to be negative, but insignificant. This observation defies economic theory which argues that when interest rates are high, the demand for credit is low because of the high cost of borrowing. When interest rates are high, the demand for goods and services is expected to slow down or remain static ceteris paribus. The coefficients for fuel price, household income, and producer price index were insignificant, though positive. The coefficient of determination was as expected - 74\% for R-squared and $73 \%$ for the Adjusted R-squared. The Durbin-Watson statistic of 2.32 shows that there is no serial autocorrelation in the variables. It is safe to say that the model is reliable. The results show that, in South Africa, the relationship between the passenger vehicle purchase decision and economic factors is weakly positive, but insignificant, suggesting that psycho-social factors influence the purchase decision. Consistent with apriori expectations, this study argues that interest rates have no role to play in the decision-making process to purchase a passenger car. It is 
assumed that vehicle repossessions are a result of an oversight by borrowers of the impact of high interest bills on the borrower repayment capacity which results in delinquent loans.

\section{CONCLUSION AND RECOMMENDATIONS}

Higher interest rates adversely affect consumer spending decisions, especially for durable goods such as automobiles. Despite the introduction of the National Credit Act, the demand for consumer credit in South Africa has increased unabated. When interest rates are high, it is a sign of overall high level of consumer demand for goods and services. In the automobile industry, it shows that the demand for vehicles is relatively high. This article aimed at understanding the economic model of consumers' passenger vehicle purchase decision. To this end, the primary objective of the paper was to determine the relationship between interest rates and the vehicle purchase decision in South Africa using the OLS regression model.

Our results show that interest rates are negatively related to the purchase decision for passenger vehicles, but the relationship is insignificant. This implies that, by and large, South African consumers will apply for credit to purchase a passenger vehicle irrespective of whether interest rates are high or low. Household income, the price of the passenger vehicle and the price of fuel were all found to be positive but weakly related to the purchase decision.

It is clear from the results of this research that economic factors do not play a significant role in the passenger vehicle purchase decision. We conclude that the consumer will purchase a passenger vehicle as long as there is access to credit. This suggests that the cost of credit and, hence the total cost of acquiring the vehicle, are not a significant factor in the decision-making process. On the basis of this conclusion, we recommend further research based on a survey on the link between psycho-social factors and the passenger vehicle purchase decision in South Africa. Our results have policy implications for the education of borrowers to avert cases of loss of assets, stress, and family disintegration.

\section{AUTHOR INFORMATION}

Mr. Joseph Chisasa is a Senior Lecturer in the Department of Finance, Risk Management and Banking of the University of South Africa. He holds a Master of Science Degree in Finance and Investment and a Bachelor of Commerce Degree in Banking (Honours). He is a Certified Associate of the Institute of Bankers of South Africa, Associate Member of the Institute of Bankers of Zimbabwe and an Associate Member of the Institute of Credit Management of South Africa. He has published in the International Business and Economics Research Journal. His research interests are in banking and credit risk management. E-mail: Chisaj@unisa.ac.za (Corresponding author)

Ms Winnie Dlamini is a lecturer in the Department of Business Management and specialising in Purchasing and Supply Chain Management at the University of South Africa (UNISA). She holds a Bachelor of Business Administration degree, (Honours) Bachelor of Commerce, and Senior Primary Teachers Diploma. Her research

interests are in procurement policies and practices and risk management. She is a member of Chartered Institute of Purchasing and Supply. Address: University of South Africa, P.O. Box 392, Pretoria 0003, South Africa. E-mail: dlamiw@unisa.ac.za

\section{REFERENCES}

1. Alper, C.E. \& Mumcu, A. 2007. Interaction between price, quality and control of origin when estimating automobile demand: the case of Turkey. Applied Economics, 39:1789-1796.

2. Banerjee, S. 2010. Study on consumer buying behavior during purchase of a second car. Journal of Marketing \& Communication, 6(2): 4-13.

3. Bhasin, H. August 2010. Factors affecting buying behavior. Available at: http://www.marketing91.com/factors-affecting-consumer-buying-behavior/ [Accessed on 24 May 2012].

4. Blumenberg, E. \& Pierce, G. 2012. Automobile ownership and travel on the poor: Evidence from the 2009 national household travel survey. Paper presented at the Transportation Research Board $91^{\text {st }}$ Annual Meeting. 
5. Brennan, L. \& Alexiades, S. 2005. Vulnerable consumers and debt: can social marketing assist? In Associate Professors Ruth Rentschler and John Hall (ed.). Proceedings of the $2^{\text {nd }}$ Australasian Nonprofit and Social Marketing conference, Geelong, Australia, 22-23 September 2005.

6. Cheng, H. K., Sims, R. R. \& Teegen, H. 1997. To purchase or to pirate software: An empirical study. Journal of Management Information Systems, 13(4): 49-60.

7. Credit Bureau Monitor, Fourth Quarter, December, 2010. Available at http://www.ncr.org.za/archieves/credit_report.php [Accessed on 27 May 2012].

8. Dasgupta, S., Siddarth, S. \& Silva-Risso, J. 2007. To lease or to buy? A structural model of a consumer's vehicle and contract choice decisions. Journal of Marketing Research, XLIV: 490-502.

9. Diaz-Olvera, L., Plat, D. \& Pochet, P. 2008. Household transport expenditure in Sub-Saharan African cities: Measurement and analysis. Journal of Transport Geography, 6:1-13.

10. Doyle, M. P. 1997. Unpublished. The effects of interest rates and taxes on new car prices. Available on http://papers.ssm.com [Accessed 2012-06-30].

11. Feng, Q., Wang, Z. \& Zeng, D. G. 2011. Household vehicle consumption forecasts in the United States, 2000 to 2025. International Journal of Market Research, 53(5): 593-618.

12. FinScope Press Release. January 2009. Available at: http://www.finscope.co.za [Accessed on 22 May 2012].

13. Kapoor, J.R., Dlabay, L.R., and Hughes, R.J. 2010. Focus on Personal Finance: An active approach to help you develop successful financial skills. McGraw-hill.

14. Lane, B. \& Potter, S. 2007. The adoption of cleaner vehicles in the UK: exploring the consumer attitudeaction gap. Journal of Cleaner production, 15(11-12): 1085-1092.

15. Mail \& Guardian. May 2012. Available at: http://mg.co.za/article/2012-05-03-new-vehicle-sales-up-105/ [Accessed on 03 June 2012]

16. Majeske, K.D., Menk, D.M. \& Serocki, J.S. An economic impact model for evaluating the automobile purchase decision. International Journal of Business Insights and Transformation, 4(2): 4-13.

17. Makatouni, A. 2002. What motivates consumers to buy organic food in the UK?: Results from a qualitative study. British Food Journal, 104(3): 345-352.

18. McManus, W. 2007. The link between gasoline prices and vehicle sales: Economic theory trumps conventional Detroit wisdom. Business Economics, January 2007:53-60.

19. Mogridge, M. J. H. 1967. The prediction of car ownership. Journal of Transport Economics and Policy, 5274.

20. Moodley, D. 2007. Consumer behaviour of the black middle class within the passenger vehicle market in South Africa. Dissertation submitted to the Gordon Institute of Business Science, University of Pretoria, in partial fulfillment of the requirements for the degree of Master of Business Administration.

21. Munchanda, P., Ansari, A. \& Gupta, S. 1999. The "Shopping Basket": A model for multicategory purchase incidence decisions. Marketing Science, 18(2): 95-114.

22. Nagai, Y., Fukuda, A., Okada, Y. \& Hashino, Y. 2003. Two-wheeled vehicle ownership trends and issues in the Asian region. Journal of the Eastern Asia Society for Transportation Studies, 5:135-146.

23. National Automobile Association of South Africa (NAAMSA). Available at: http://www.naamsa.co.za/ [Accessed on 20 May 2012].

24. Naude, M.J. \& Badenhorst-Weiss, J.A. 2011. Supply chain management problems at South African component manufacturers. South African Business Review, 15(1): 70-99

25. Personal Finance Research Unit (PFRU). November 2011. Available at: http://www.unisa.ac.za/default.asp?Cmd=ViewContent\&ContentID=26776 [Accessed on 23 May 2012].

26. Rahman, A. 2011. An empirical study of the relationship between car loan and lifestyle of people of Bangladesh. Interdisciplinary Journal of Contemporary Research Business, 3(2): 1276-1291.

27. Rimal, A. P., Moon, W. \& Balasubramanian, S. 2005. Agro-biotechnology and organic food purchase in the United Kingdom. British Food Journal, 107(2): 84-97.

28. Shah, A. 2010. Factors affecting consumer behavior. Available at: http://www.aipmm.com/html/newsletter/archives/000434.php Accessed on 04 June 2012.

29. South African Petroleum Industry Association. Available at: http://www.industry-overview/stats-andgraphs.html [Accessed: 31 May 2012].

30. South African Reserve Bank. Available at: http://www.resbank.co.za [Accessed on 25 May 2012]. 
31. Trading Economics. Available at: http://www.tradingeconomics.com/south-africa/interest-rate Accessed on 04 June 2012.

32. Van Rijnsoever, F., Farla, J., \& Dijst, M.J. 2009. Consumer car preferences and information search channels. Transportation Research part D: Transport and Environment, 14(5): 334-342.

33. Wonder, N., Wilhelm, W. \& Fewings, D. The financial rationality of consumer loan choices: Revealed preferences concerning interest rates, down payments, contract length and rebates. The Journal of Consumer Affairs, 42(2): 243-270.

34. Zhan, J. \& Vrkljan, B. (n.d.) Exploring factors that influence vehicle purchase decisions of older drivers: Where does safety fit? Proceedings of the Sixth International Driving Symposium on Human Factors in Driver Assessment, Training and Vehicle Design. 
NOTES 